\title{
Pembentukan perilaku ekonomi yang berwawasan pancasila melalui penerapan pendidikan ekonomi di lingkungan
}

\author{
Aida Nurcholida*, Muhamad Zunaidi \\ Universitas Negeri Malang, Jl. Semarang No. 5 Malang, Jawa Timur, Indonesia \\ *Penulis korespondensi, Surel: aidha.nurcholida@gmail.com
}

Paper received: 2-2-2021; revised: 20-2-2021; accepted: 27-2-2021

\begin{abstract}
Abstrak
Lembaga pendidikan Islam tertua di Indonesia menjadikan pesantren tempat tumbuhnya perkembangan Islam nusantara. Seiring perkembangan zaman menjadikan pesantren untuk terus berbenah kearah yang lebih baik, dengan adanya kurikulum agama beserta pembentukan nilai-nilai yang ada pada santri terutama yang berkaitan dalam pendidikan berkarakter yang sesuai dengan jati diri Bangsa Indonesia yang memiliki landasan ideologi pancasila kepada para santri. Pendidikan karakter sudah menjadi ciri khas dalam lembaga pendidikan pondok pesantren sehingga para santri bisa memiliki karakter yang religius dan karakter mandiri. Pesantren memberikan pendidikan karakter dengan melalui kegiatan yang dilakukan secara rutin yang mana setiap kegiatan sehari- hari mulai seharian penuh atau 24 jam sehingga sistem pendidikan yang ada di pesantren. Tujuan dari penelitian ini untuk menganalisis peran Pondok pesantren sebagai tempat pembelajaran pendidikan ekonomi yang memiliki karakter Pancasila sesuai dengan sistem ekonomi yang diterapkan di indonesia yaitu ekonomi Pancasila kepada para generasi milenial. Sehingga dengan adanya pendidikan karakter yang memiliki nilai- nilai Pancasila di suatu lembaga formal terutama didalam pesantren dapat membentuk kemampuan intelektual, emosional dan pembentukan karakter religius sehingga dapat memunculkan generasi yang tidak hanya cerdas tapi juga memiliki keilmuan yang baik, berakhlakul karimah dan karakter yang sesuai dengan jati diri bangsa terutama dalam hal di bidang ekonomi.
\end{abstract}

Kata kunci: pesantren; karakter; ekonomi; pancasila

\section{Pendahuluan}

Pondok pesantren telah terkenal sebagai lembaga pendidikan berbasis islam yang paling tertua di indonesia. Pada zaman penjajahan pesantren memiliki peran yang sangat besar dalam memperjuangan kemerdekaan bangsa. Pondok Pesantren merupakan lembaga pendidikan yang memiliki asrama yang mana disana berada dibawah pimpinan para kyai, ustadz atau ulama yang akan tinggal bersama santri di lingkungan pesantren dengan adanya masjid sebagai pusat kegiatan keagamaan pesantren. Pesantren memiliki model yang memiliki karakteristik yang sangat khas, yang mana kegiatan pendidikan yang ada didalamnya dilakukan dalam kurun waktu seharian penuh atau 24 jam, yang mana didalamnya terdapat berbagai jenis pendidikan baik secara keagamaan yang menjadi hal wajib ada disana, sosial kemasyarakatan, serta pengembangan potensi umat.

Pesantren selain menjadi wadah pendidikan yang dapat bersaing dengan lembaga pendidikan formal atau pendidikan umum yang berada dibawah naungan kementrian agama. Dari segi kualitas maupun kuantitas pesantren juga tidak akan kalah bersaing dengan lembaga pendidikan pada umumnya. Saat ini pesantren memiliki tuntutan untuk selalu mengikuti perkembangan zaman, kemajuan ilmu dan teknologi sehingga pesantren tidak akan kalah dengan pendidikan formal yang lainnya dengan mencetak para santri yang bisa survive dalam dunia luar.

This work is licensed under a Creative Commons Attribution-ShareAlike 4.0 International License. 
Reformasi dan inovasi di pesantren perlu dilakukan oleh Kementrian agama dan para pengelola pesantren yang menaungi kelembagaan pesantren terutama dalam hal perubahan kurikulum serta metode mengajar yang dilakukan dalam kegiatan pembelajaran. Menurut Mar'ati (2014) mengatakan bahwa pendidikan yang ada di pesantren merupakan garda utama dalam membentuk pendidikan moral bangsa karena di dalam pesantren memiliki nilai agama yang kuat, dan sebagai penyokong utama sistem pendidikan nasional. Maka dari itu eksistensi pesantren perlu dilakukan agar pesantren dapat menjawab tantangan zaman sehingga nantinya dapat melahirkan santri- santri professional dimanapun dia berada dan dari segi kualitas tidak akan kalah bersaing atau setara dengan lulusan sekolah umum atau bahkan bisa lebih baik lagi.

Membentuk generasi yang cerdas serta memiliki karakter yang baik dan kuat menjadi salah satu faktor yang penting dalam membangun bangsanya kearah yang lebih terarah menuju hal yang baik, Sehingga pendidikan menjadi bagian yang sangat penting dalam pembentukan karakter terutama di pesantren yang berkaitan dengan pendidikan ekonomi hal ini dilakukan agar bisa menghasilkan orang yang profesional dalam bidang ekonomi.

Fenomena yang ada sudah menjadi tugas, kewajiban serta tanggung jawab semua orang secara bersama- sama mulai dari unit terkecil yaitu keluarga, masyarakat dan pemerintah agar bisa segera menemukan solusi dari setiap masalah yang ada agar terdapat perbaikan melalui penyusunan suatu formula dalam pendidikan karakter bisa lebih baik lagi. Pesantren menjadi penerapan model pendidikan karakter yang diberlakukan seperti pada sekolah pada umumnya karena pendidikan karakter yang ada di pesantren menjadi sebuah transfer pendidikan yang mana dapat membentuk suatu kebiasaan- kebiasaan yang nantinya disana adanya pembiasaan yang bernilai yang dilakukan dalam kegiatan sehari- sehari yang mana di dalam pesantren menekankan pada suatu kebiasan yang mengarah kepada suatu hal yang baik sesuai dengan nilai- nilai kultur dan kepribadian yang berlandaskan pada agama ketika berada di asrama maupun pondok.

Pendidikan karakter memiliki suatu Pedoman yang telah diterbitkan oleh Kementerian Pendidikan Nasional tahun 2011, yang mengatakan bahwa pendidikan karakter menjadi suatu pendidikan yang dapat membentuk nilai, budi pekerti, moral, pendidikan watak yang memiliki tujuan untuk mengembangkan keahlian serta kemampuan peserta didik sehingga mampu mengambil sebuah keputusan secara tepat dengan memperhatikan dampak baik maupun buruk. Membentuk bangsa yang tangguh, bermoral, berakhlak mulia, bertoleransi, serta bergotong royong, berkembang secara baik yang berorientasi pada ilmu pengetahuan dan teknologi yang berkembang saat ini yang semuanya dapat dijiwai dengan iman dan takwa kepada tuhan yang maha esa berdasarkan Pancasila merupakan tujuan dari adanya pendidikan karakter. Karakter yang biasa ada pada diri manusia terbagi menjadi tiga bagian yang saling berkaitan seperti pengetahuan yang berkaitan dengan moral (moral knowing), kedua mengenai perasaan (moral feeling), Ketiga, perilaku bermoral (moral behaviour). (Oktari and Kosasih, 2019)

Pendidikan ekonomi merupakan suatu komponen proses dalam memberikan pembelajaran mengenai suatu perilaku serta tindakan manusia dalam memenuhi suatu kebutuhan hidup bagi para santri. Pembelajaran pendidikan ekonomi menjadi dasar dalam pembelajaran moral untuk para peserta didik terutama santri yang ada di pondok pesantren dalam meletakkan hal yang menjadi dasar dalam berperilaku ekonomi yang baik dan benar. 
Proses kegiatan belajar mengajar menjadi hal yang penting dan haruslah berkualitas dengan cara melibatkan para santri untuk selalu aktif agar santri juga bisa menerapkan nilai-nilai yang terkandung dalam Pancasila melalui adanya revitalisasi budaya yang dimiliki bangsa Indonesia yang didalamnya didominasi oleh nilai- nilai kebersamaan yang nantinya bisa dipadukan dengan adanya pelaksanaan sistem ekonomi Pancasila yang ada di indonesia.

Pondok pesantren menjadi lembaga pendidikan islam yang memiliki potensi dalam menerapkan pemberdayaan umum terutama berkaitan dengan bidang ekonomi. Karena dengan menjalankan kegiatan pemberdayaan dalam bidang ekonomi bisa menjadi ajang untuk melakukan dakwah sekaligus untuk mengimplementasikan ilmu- ilmu yang dimiliki secara konkrit (aplikatif) dalam kehidupan bermasyarakat sehari- hari. Dalam agama islam itu sendiri ekonomi menjadi suatu wasilah bukan maqashid maka ekonomi menjadi salah satu hal yang bisa dilakukan untuk mencapai suatu kebahagiaan dunia serta kehidupan kekal di akhirat. Maka dari itu sangat penting bagi santri yang berada dalam pondok pesantren untuk mempelajari mengenai pendidikan ekonomi karena dalam islam sendiri bahwa segala hal yang ada dimuka bumi termasuk harta serta kegiatan ekonomi merupakan suatu amanah dari allah SWT sebagai pemilik hakiki segalanya termasuk kekayaan.

Adanya pesantren sebagai tempat untuk membangun suatu budaya yang berasal dari agama, masyarakat dan negara diperlukan pembiasaaan baik sejak dini, maka dari itu pesantren memfasilitasi untuk melakukan kebiasaan baik di lingkungan pesantren hal ini dilakukan untuk membentuk perilaku yang berdasarkan nilai- nilai Pancasila sebagai bentuk pengimplemantasian nilai Pancasila yang diterapkan oleh negara serta adanya pembelajaran ekonomi yang sudah ada dan selalu kita lakukan dalam kegiatan beraktivitas sehari- hari dalam kehidupan bersosial masyarakat selama yang ada di pesantren agar nantinya masyarakat mampu menggunakan keduanya dijalan yang benar sea mampu memberikan keseimbangan dalam pemenuhan kebutuhan yang dapat menjadi obat untuk menghilangkan kehampaan dalam diri setiap orang.

\section{Metode}

Penelitian yang terdapat pada artikel ini menggunakan suatu metode penelitian deskriptif kualitatif adalah metode yang dipergunakan untuk memberikan gambaran serta analisis mengenai hasil penelitian. Selain itu peneliti menggunakan penelitian kepustakaan (Library Research) yang mana merupakan bahan penelitian yang bersumber dari berbagai macam literatur perpustakaan serta melalui penelitian terdahulu yang terdapat pada beberapa artikel ilmiah. Penelitian kualitatif dilakukan dengan menjelaskan penelitian tersebut secara deskripsi, melalui gambaran secara sistematis, akurat, dan faktual mengenai suatu fakta, sifat serta hubungan antar suatu kejadian atau fenomena yang diamati. Analisa data yang digunakan menggunakan metode content analisis yang biasanya digunakan untuk menganalisis suatu pendapat seseorang kemudian ditambah dengan pendapat dari peneliti yang lain lalu dibuatlah kesimpulan dari beberapa literatur yang ada.

\section{Hasil dan Pembahasan}

Perkembangan zaman sekarang yang semakin maju, penerapan teknologi, informasi dan komunikasi yang begitu pesat serta sangat sulit dibendung, mempermudah segala kegiatan yang dilakukan oleh manusia sekarang termasuk remaja bahkan anak- anak. generasi penerus bangsa sangat berpengaruh pada pembiasaan karakter akhlak mereka hal ini tentu menjadi tantangan yang dihadapi di oleh pendidik sekarang menjadi cukup berat karena dengan 
masuknya budaya- budaya asing melalui teknologi yang ada membuat menurunnya nilai- nilai moral, budi pekerti luhur, karakter maupun akhlak yang dimiliki peserta didik saat ini hal ini terbukti dengan banyaknya berita- berita yang dimuat di berbagai surat kabar maupun media televisi maupun social media bahwa banyak sekali kasus remaja seperti pergaulan bebas, tawuran penyalahgunaan narkoba.

Fenomena yang ada sudah menjadi tugas dan tanggung jawab semua orang secara bersama- sama mulai dari unit terkecil yaitu keluarga, masyarakat dan pemerintah agar bisa segera menemukan solusi dari setiap masalah yang ada agar terdapat perbaikan melalui penyusunan suatu formula dalam pendidikan karakter bisa lebih baik lagi. Pesantren menjadi penerapan model pendidikan karakter yang diberlakukan seperti pada sekolah pada umumnya karena pendidikan karakter yang ada di pesantren menjadi sebuah transfer pendidikan yang mana dapat membentuk kebiasaan serta budaya yang ada di sekolah dengan melakukan pembiasaan melalui hal yang bersifat positif dalam kegiatan sehari- sehari yang mana di dalam pesantren menekankan pada suatu kebiasan yang mengarah kepada suatu hal yang baik dan nilai- nilai kultur dan kepribadian yang berlandaskan pada agama ketika berada di asrama maupun pondok. Pondok pesantren memiliki peran yang besar untuk mencetak para peserta didik atau santri yang mandiri, sehingga tidak selalu untuk menggantungkan hidupnya kepada orang lain. Karena didalam pesantren para santri memang harus dibiasakan untuk tinggal sendiri di pesantren mereka tinggal jauh dari orang tuanya sehingga apabila terdapat masalah dapat dilakukan dan diselesaikan secara mandiri.

Pancasila itu sendiri menjadi ideologi serta falsafah negara yang menjadi pedoman dalam berbangsa dan bertanah air hal ini sesuai yang ada pada UUD 1945. Dalam UUD 1945 pun disebutkan bahwa Pancasila merupakan suatu pedoman masyarakat agar bisa meraih suatu kebahagiaan, kesejahteraan, perdamaian, serta kemerdekaan untuk sebuah negara yang berdaulat. Indonesia sendiri merupakan negara yang kaya dengan segala hal tentu saja membuat indonesia menjadi negara yang tidak terlepas dari para penjajah yang dilakukan oleh beberapa negara hal ini menjadikan perekonomian Indonesia masih dipengaruhi oleh hal - hal yang telah diajarkan oleh para penjajah, akan tetapi adanya semangat bergotong royong masyarakat dalam melakukan berbagai hal ini menjadikan kegiatan gotong royong menjadi jati diri sesungguhnya yang sudah sangat melekat dalam diri rakyat Indonesia sehingga pada akhirnya identitas tersebutlah yang menjadi ciri khas perekonomian negara Indonesia. Gotong royong sendiri menjadi suatu kegiatan yang biasa dilakukan oleh masyarakat secara bersamasama dalam hal ini menjadikan ekonomi Indonesia haruslah bisa menerapkan kegiatan usaha bersama ini agar dalam melakukan kegiatan bisa dilakukan dengan mudah dan lebih ringan. Kegiatan ekonomi yang dilakukan dengan saling menjalankan sebuah usaha tanpa harus mengganggu aktifitas pengusaha yang lainnya terutama usaha yang kecil.

Hal ini sesuai dengan pernyataan dari (Wahjoedi:2013) yang mengatakan bahwa dalam ekonomi Pancasila memiliki karakter yang memuat suatu pesan konstitusi, yang didalamnya terdapat nilai-nilaI luhur Pancasila yang bisa menjadi bagian dari falsafah hidup bangsa Indonesia maka dari itu adanya nilai Pancasila ini harus bisa dikenalkan kepada seorang anak sejak dini terutama dalam lingkup keluarga beserta melalui pendidikan formal terutama di pesantren untuk memberikan proses pembelajaran yang baik berkaitan dengan pendidikan ekonomi di lembaga pendidikan terutama di pesantren. Nilai- nilai yang terkandung dalam ideology Pancasila telah memuat nilai-nilai luhur kepribadian bangsa Indonesia yaitu adanya nilai kekeluargaan, kerjasama, lebih mengutamakan kepentingan kebersamaan diatas 
kepentingan perorangan atau individu, berarti juga berpihak kepada rakyat. Ekonomi Pancasila dikembangkan untuk menciptakan keadilan sosial bagi seluruh rakyat Indonesia, yang diwujudkan dalam tatanan masyarakat adil dan makmur. Pendidikan ekonomi menjadi suatu hal berupa kombinasi yang mengaitkan antara komponen- komponen dalam sebuah proses yang mampu mengajarkan mengenai perilaku serta tindakan yang dilakukan manusia untuk memenuhi segala kebutuhan dari manusia terutama peserta didik. Pembelajaran ekonomi merupakan sebuah dasar pembelajaran moral untuk peserta didik mengenai hal- hal untuk meletakkan suatu dasar dalam berperilaku ekonomi yang sesuai. Kegiatan pembelajaran yang berkualitas harus memiliki sifat yang aktif agar nantinya memiliki nilai- nilai pancasila yang dipadukan antara nilai- nilai kebersamaan dengan pelaksanaan sistem ekonomi yang ada dalam kehidupan bermasyarakat terutama di pesantren. Adanya nilai kegotongroyongan serta kekeluargaan merupakan tradisi serta adat yang ada di dalam masyarakat yang nantinya bisa ditransformasikan dalam kegiatan berekonomi.

Kegiatan ekonomi yang tercermin dalam Pancasila yaitu terutama pada sila pertama yang mana ada di dalam ekonomi islam atau syariah dengan dasar bahwa ketuhanan akan sejalan dengan ajaran islam, kegiatan ekonomi yang ada di masyarakat dilihat juga dengan kultural masyarakat yang mayoritas beragama tentu saja hal ini menjadi adanya aturan- aturan beragama dalam berekonomi sehingga apa yang dilakukan selalu berpijak pada segala aturan atau hukum islam yang mengarah pada kebijakan- kebijakan yang berkaitan dengan bidang ekonomi yang disesuaikan berdasarkan perspektif islam. Maka ekonomi Pancasila yang sudah ada didalam masyarakat Indonesia bisa diterapkan dengan sudut pandang islam. Ekonomi Pancasila yang berlandaskan dengan Pancasila yang merupakan ideology bangsa Indonesia. Semua elemen dalam negara terutama pemerintah dan masyarakat memiliki kewajiban untuk ikut andil dalam mengutamakan ekonomi rakyat dengan menerapkan ekonomi Pancasila demi mewujudkan kemakmuran serta kesejahteraan rakyat.

Ekonomi pancasila yang selama ini diterapkan di Indonesia pun memiliki sistem sesuai dengan Pancasila sila yang pertama bahwa, Ketuhanan Yang Maha Esa: yang didalamnya memiliki makna bahwa setiap warga yang ada negara ini telah digerakkan oleh beberapa rangsangan seperti ekonomi, sosial dan moral. Sila yang kedua, yaitu Kemanusiaan yang adil dan beradab: yang mana didalamnya memiliki makna bahwa adanya tekad besar yang dimiliki seluruh bangsa indonesia untuk mewujudkan adanya pemerataan sosial. Sila yang Ketiga, Persatuan nasional: yang mana menunjukkan bahwa didalam Pancasila harus menerapkan nasionalisme ekonomi. Sila Keempat, Kerakyatan yang dipimpin oleh hikmat kebijaksanaan dalam permusyawaratan/ perwakilan: hal ini mengindikasikan bahwa masyarakat dalam melakukan kegiatan ekonomi juga perlu adanya demokrasi. Hal ini sesuai salah satu pendapat Emil Salim yang mana beliau memberikan suatu konsepsi mengenai adanya sistem ekonomi pancasila yang dianut bangsa Indonesia yang mana mengatakan bahwa Manusia yang menjadikan pancasila sebagai ideologi berbangsa tentu saja memberikan kesimbangan dalam melakukan segala hal terutama adanya suatu usaha antara kerja yang harus diikuti dengan ikhtiar atau doa sebagai makhluk yang berketuhanan, berprikemanusiaan, memiliki kedaulatan rakyat, serta berkeadilan sosial dan berkebangsaan. Dalam kegiatan Ekonomi pancasila yang diterapkan oleh masyarakat Indonesia biasanya tidak mentolerir adanya caracara produksi dengan melakukan berbagai hal yang berperikemanusiaan seperti mengeksploitasi sesama manusia. Selain itu Sistem ekonomi Pancasila yang diterapkan bisa jadi memungkinkan adanya pengembangan unsur kemanusiaan serta dan mendapatkan keyakinan yang kuat dalam hati sanubari seluruh masyarakat Indonesia. Selain itu dalam 
Ekonomi Pancasila juga menjelaskan bahwa ekonomi Pancasila memiliki posisi sebagai penengah atau penetralisasi adanya sistem ekonomi terpimpin dan adanya ekonomi pasar. Ekonomi Pancasila merupakan ideology yang memiliki pemahaman mengenai demokrasi dalam melakukan kegiatan ekonomi yang dalam melakukan kegiatan tersebut memiliki asas keseimbangan. Terakhir bahwa adanya penerapan ekonomi Pancasila juga adanya kontrol arah perkembangan ekonomi yang sesuai dengan target yang diinginkan melalui rencana yang telah disusun.

Pendidikan ekonomi yang ada di pesantren menerapkan pembelajaran yang berbasis ekonomi islam yang mana ekonomi islam merupakan sebuah aktivitas perekonomian yang didalamnya memiliki dasar berupa AL-Qur'an dan Al- Hadist. Sedangkan yang ada di indonesia sendiri memiliki karakteristik ekonomi Pancasila yang merupakan sistem perekonomian yang bersumber terhadap ideology yang ada di Pancasila. Indonesia merupakan negara yang percaya adanya ketuhanan yang maha esa serta mempunyai tujuan untuk memperjuangkan sesuatu yang ada di Pancasila yaitu kemanusiaan yang adil dan beradab yang mana hal ini telah dicantumkan dalam UUD 1945 adalah pedoman dasar bangsa Indonesia. Sehingga hal ini menunjukkan bahwa ketuhanan yang ada didalam Pancasila menegaskan etika untuk melakukan berbagai hal dengan selalu menjunjung tinggi nilai- nilai agama termasuk dalam bidang ekonomi itu sendiri.

Pancasila merupakan suatu ideologi yang memiliki keterkaitan sangat erat dengan alqur-an sebagai suatu dasar atau sumber adanya ekonomi islam sehingga adanya ekonomi islam yang diterapkan di pesantren menjadi dasar dalam melakukan kegiatan ekonomi Pancasila, diantaranya: (1) Sila pertama, yang berbunyi "Ketuhanan yang maha esa" dalam sila ini kita diajarkan untuk selalu mesakan tuhan sehinga harus selalu tertanam dalam diri setiap muslim. (2) Sila kedua, yang memiliki bunyi "Kemanusiaan yang adil dan beradab" merupakan semangat yang diajarkan agama Islam untuk menjunjung tinggi adanya nilai- nilai kemanusiaan yang bisa diterapkan di segala dimensi kehidupan. (3) Sila ketiga yang berbunyi "Persatuan Indonesia" telah menjadi suatu harapan serta cita- cita bangsa yang juga telah ada dalam ajaran Islam yang mana kita diperintahkan untuk selalu menjaga persatuan dan kesatuan kepada sesama manusia dimuka bumi terutama sesama muslim yang telah menjadi saudara. (4) Sila keempat, "Kerakayatan yang dimpin oleh hikmat kebijaksanaan dalam permusyawaratan perwakilan" hal ini sesuai yang ada pada Islam bahwa dalam melalkukan berbagai hal akan lebih baik apabila dilakukan secara bersama dan saling membantu dengan saling merigankan beban orang lain. (5) Sila yang terakhir berbunyi "Keadilan Sosial bagi seluruh rakyat Indonesia" yang mana hal ini sesuai yang diajarkan oleh agama bahwa kita harus selalu adil dalam berbuat kebaikan kepada semua mahkluk yang ada dimuka bumi dengan menghindari perbuatan yang keji.

Dalam penerapan pendidikan ekonomi di pesantren diberikan pembelajaran yang memiliki nilai- nilai Islam sesuai dengan background yang ada di pesantren yang merupakan lembaga pendidikan belajar yang berbasis islam sehingga tentu saja dalam pendidikan ekonominya berbasis islam atau biasa disebut ekonomi islam. Adapun nilai- nilai yang terdapat pada ekonomi Islam yang sesuai dengan ekonomi Pancasila sesuai dengan dasar ekonomi Indonesia menurut (Akbar \& Ghufron, 2019) yaitu diantaranya:

(1) Ekonomi Islam serta ekonomi Pancasila keduanya memiliki kesamaan visi social serta moral yang mana adanya tujuan dalam melakukan kegiatan ekonomi yang sesuai dengan 
keadaan social dan moral yang ada. (2) Keduanya adanya keinginan dalam mewujudkan keadilan serta pemerataan social bahkan adanya jaminan sosial dalam melakukan segala hal entah itu baik maupun buruk selalu memiliki dampaknya. (3) Adanya rasa nasionalisme ekonomi yang mana semangat kekeluargaan dan saling mencintai dan tenggang rasa, sehingga dalam kehidupan bermasyarakat harus memiliki solidaritas sosial dalam menjadi kemerataan sosial. (4) Adanya Koperasi (Baitul Mal Wat Tamwi) yang merupakan menjadi suatu kekuatan dalam melakukan kegiatan berekonomi. Semua yang ada pada di muka bumi termasuk Harta yang ada dalam agama Islam merupakan milik Allah SWT, yang nantinya akan dimanfaatkan untuk kepentingan bersama. Adanya baitul mal wat tamwi memiliki tujuan yang sama persis dengan tujuan didirikannya koperasi. (5) Antara ekonomi Islam dan ekonomi Pancasila memiliki kesamaan dalam keseimbangan untuk melaksanakan kebijakan ekonomi. Dalam alqur'an Allah sudah menjelaskan bahwa harta benda, kekayaan dan segala hal yang ada dimuka bumi ini merupakan milik Allah. Maka makhluk hidup yang ada di dimuka bumi memiliki kewajiban untuk ikut memelihara kepentingan bersama.

Adanya ekonomi Islam di pesantren diwujudkan dengan adanya pembelajaran pendidikan ekonomi di lingkungan pesantren karena kegiatan ekonomi merupakan yang dakwah yang bisa dilakukan untuk untuk mengimplementasikan ilmu- ilmu yang dimiliki secara konkrit (aplikatif) dalam kehidupan bermasyarakat sehari- hari. Dalam agama islam itu sendiri ekonomi adalah suatu wasilah bukan maqashid sehingga ekonomi menjadi salah satu hal yang bisa dilakukan untuk mencapai suatu kebahagiaan dunia serta kehidupan kekal di akhirat. Maka dari itu sangat penting bagi santri yang berada di pondok pesantren untuk mempelajari mengenai pendidikan ekonomi karena dalam islam sendiri bahwa segala hal yang ada dimuka bumi termasuk harta serta kegiatan ekonomi merupakan suatu amanah dari allah SWT sebagai pemilik hakiki segalanya termasuk kekayaan tentu saja dapat menjadi upaya pesantren untuk melakukan pembentukan perilaku ekonomi yang memiliki wawasan Pancasila, Karena pembelajaran karakter berwawasan Pancasila sudah sangat diterapkan di pesantren karena mereka dibentuk untuk menjadi santri yang memiliki karakter berakhlakul karimah yang memiliki sopan santun sesuai dengan karakter dasar negara kita yaitu Pancasila.

\section{Simpulan}

Penerapan pendidikan karakter telah menjadi suatu hal yang teramat penting agar bisa diterapkan dalam kehidupan manusia maka perlu diterapkan sejak dini. Pesantren menjadi salah satu tempat yang terbaik untuk dapat menerapkan pendidikan karakter siswa. Karena pesantren merupakan model pendidikan yang paling tertua dan khas di Indonesia sejak zaman penjajahan karena pesantren menjadi lembaga pendidikan berbasis Islam yang memiliki peran sangat penting dalam mengiringi peradaban negeri ini. Pendidikan karakter di pesantren perlu diterapkan karena didalamnya terdapat nilai- nilai luhur penerapan pendidikan karakter.

Peran para pengurus di dalam pondok pesantren mulai dari berbagai SDM yang ada seperti peran kyai dan ustadzah sangat vital sebagai sosok yang memiliki peran sangat penting dalam memberikan pendidikan karakter untuk para anak muda saat ini. Karena kyai dan ustadzah atau pendidik yang ada di dalam pesantren memberikan contoh, ucapan, karakter dan kepribadian menjadi cerminan untuk bisa dilakukan para santri.

Pendidikan ekonomi menjadi salah satu disiplin ilmu sosial yang merupakan ilmu yang wajib dipelajari untuk memenuhi kebutuhan hidup dari manusia. Manusia itu sendiri dalam memenuhi kebutuhan hidup selalu bisa menghalalkan segala cara untuk mendapatkan 
kekayaan melalui keserakahan yang sudah menjadi sifat dasar manusia yang selalu merasa tidak cukup, kurang dan tidak puas. Maka dari itu selain dari keluarga, lembaga pendidikan juga memiliki peran yang teramat penting untuk membentuk karakter anak terutama dalam berperilaku ekonomi agar mereka bisa menyikapi dalam perilaku ekonomi yang bijak, Pesantren menjadi tempat yang memiliki peran besar dalam mendidik anak karena pesantren merupakan lembaga pendidikan yang memberikan penanaman moral yang memiliki dasar berbasis islam.

Penanaman karakter yang akan dimiliki seorang anak sesuai dengan ideologi Pancasila, sehingga tentu perilaku ekonomi yang berlandaskan Pancasila menjadi upaya yang bisa dilakukan bersama dalam mewujudkan usaha secara gotong royong yang memiliki tujuan dalam mewujudkan adanya keadilan sosial dalam kemakmuran dan kesejahteraan secara bersama- sama untuk memberikan perhatian terhadap kondisi sosial yang ada disekitarnya. Sehingga dalam pandangan islam ekonomi Pancasila juga menjadi sistem perekonomian yang didalamnya disesuaikan dengan adanya semangat Ekonomi Islam. Sehingga kedua sistem tersebut memiliki kesamaan tujuan untuk mewujudkan adanya keadilan dalam sosial serta kesejahteraan bersama yang didalamnya adanya pengaruh perhatian terhadap adanya kondisi sosial masyarakat yang ada disekitarnya.

\section{Daftar Rujukan}

Akbar, M. A. \& Ghufron, M. I. (2019). Sinkronisasi Ekonomi Pancasila dan Ekonomi Islam. Jurnal Masharif alSyariah: Jurnal Ekonomi dan Perbankan Syariah, 4(1). doi: 10.30651/jms.v4i1.2868.

Asmuki, A. \& Aluf, W. Al (2018). Pendidikan Karakter Di Pesantren. Edupedia, 2(2), 1-10. doi: 10.35316/edupedia.v2i2.325.

Islam, U. \& Sunan, N. (2018). Potensi dan peran pesantren dalam mengembangkan ekonomi masyarakat.

Mar'ati, R. (2014). Pesantren Sebagai Basis Pendidikan Karakter; Tinjauan Psikologis. AL-MURABBI: Jurnal Studi Kependidikan dan Keislaman, 1(1), 1-15.

Mauludin, M. \& Natalia, T. W. (2018). Penerapan Pendidikan Ekonomi Kreatif di Pesantren sebagai sarana untuk Menghasilkan Pribadi Wirausaha yang dilandasi nilai-nilai Keagamaan,

Mughni, D. I. (2018). Kemandirian Ekonomi Santri (Studi Kasus di Pondok Pesantren El-Bayan Bendasari Majenang Cilacap Jawa Tengah).

Nadzir, M. (2015). Membangun Pemberdayaan Ekonomi Di Pesantren. Economica: Jurnal Ekonomi Islam, 6(1), 37-56. doi: 10.21580/economica.2015.6.1.785.

Nofiaturrahmah, F. (2017). Metode Pendidikan Karakter Di Pesantren, Jurnal Pendidikan Agama Islam, 11(2), 201-216.

Oktari, D. P. \& Kosasih, A. (2019). Pendidikan Karakter Religius dan Mandiri di Pesantren. Jurnal Pendidikan Ilmu Sosial, 28(1)

Putri, A. R. N., Wahjoedi, W. \& Haryono, A. (2017). Pendidikan Ekonomi di Pondok Pesantren 